\title{
PERBAIKAN METODE REKOMENDASI DISKUSI PEMROGRAMAN DENGAN NORMALISASI IDENTIFIER MENGGUNAKAN LINGUA::IDSPLITTER
}

\author{
Nanang Fakhrur Rozi ${ }^{1}$, Daniel Oranova Siahaan $^{2}$, Fajar Baskoro $^{2}$ \\ ${ }^{1}$ Teknik Informatika ITATS, J1. Arief Rachman Hakim 100, Surabaya \\ ${ }^{2}$ Teknik Informatika ITS, Jl. Teknik Kimia, Kampus ITS Sukolilo, Surabaya \\ ${ }^{1}$ E-mail: nanang@itats.ac.id
}

\begin{abstract}
Stack Overflow as a question and answer (Q\&A) site has often been used as reference by programmers. Information or solutions in the software development process can be searched with the help of search engine on the site. However, differences in writing style, especially on the program identifier writing, often causing the recommendation (search) become incompatible with the programmers need. Some programmers write identifier in abbreviated form while another are not so that it lowers the recommendation performance. This research adopted the Lingua::IdSplitter to normalize the identifier on Stack Overflow discussion. The normalization process is done by separating the identifier comprising the composition of the term as well as expanding the existing abbreviation on the identifier to the full form. The results showed that the identifier normalization using Lingua::IdSplitter able to improve the median value of recall up to $13 \%$.
\end{abstract}

Keywords: recommender system, identifier, normalization, Stack Overflow

\begin{abstract}
ABSTRAK
Situs tanya-jawab Stack Overflow telah sering digunakan sebagai acuan oleh programmer. Informasi atau solusi dalam proses pengembangan perangkat lunak dapat dicari dengan bantuan mesin pencari pada situs. Namun, perbedaan dalam gaya penulisan, terutama pada penulisan identifier program, sering menyebabkan rekomendasi (pencarian) menjadi tidak sesuai dengan kebutuhan programmer. Beberapa programmer menulis identifier dalam bentuk singkatan sementara yang lain tidak sehingga menurunkan kinerja rekomendasi. Penelitian ini mengadopsi Lingua::IdSplitter untuk menormalkan identifier pada data diskusi Stack Overflow. Proses normalisasi dilakukan dengan memisahkan identifier yang terdiri atas komposisi term serta memperluas singkatan yang ada pada identifier ke bentuk penuh. Hasil penelitian menunjukkan bahwa normalisasi identifier menggunakan Lingua::IdSplitter secara umum mampu meningkatkan nilai median recall hasil rekomendasi hingga 13\%.
\end{abstract}

Kata kunci: sistem rekomendasi, identifier, normalisasi, Stack Overflow

\section{PENDAHULUAN}

Perusahaan perangkat lunak yang baik seharusnya dapat menyediakan deliverable dengan waktu yang singkat dan dengan kualitas yang baik pula. Untuk mencapai hal tersebut, dibutuhkan manajemen serta kerja sama yang baik dari setiap pemangku kepentingan terutama programmer yang menjadi tulang punggung terciptanya perangkat lunak. Dengan demikian, performa programmer yang baik merupakan keniscayaan dalam menyukseskan proyek perangkat lunak.

Dalam [1] disebutkan bahwa performa programmer dapat diukur berdasarkan kepribadian, kemampuan kognitif, serta tingkat kepercayaan terhadap nilai teoretis (theoretical value belief). Programmer yang selalu mencari pembuktian kebenaran terhadap hasil kerjanya, tidak asal-asalan dalam menyediakan solusi dalam bentuk kode program, cenderung memiliki performa yang baik dalam jangka panjang. Hal tersebut memaksa programmer, terutama programmer pemula, untuk menginvestasikan waktunya dalam meningkatkan kemampuan terkait pemahaman algoritma, cara memprogram, informasi-informasi pendukung, atau hal-hal lain yang berkaitan dengan perangkat lunak yang akan dibangun. Mendapatkan informasi dari anggota tim atau teman kerja menjadi 
salah satu carankya [2]. Namun, hal itu akan membebani anggota lain untuk juga meluangkan waktu yang pada akhirnya akan berimbas pada perlambatan waktu delivery. Guna menghindari hal tersebut, cara lain pun ditempuh. Seiring perkembangan web 2.0, informasi-informasi berguna terkait proses pengembangan perangkat lunak yang ditenagai oleh komunitas tersedia di internet, antara lain yang berbentuk situs tanya-jawab [3]. Media tersebut pada akhirnya banyak digunakan oleh pengembang perangkat lunak untuk mendapatkan solusi atas masalah-masalah yang dihadapi. Media tersebut dapat berupa sebagian dari platform media sosial seperti grup di Facebook atau situs khusus seperti Stack Overflow.

Stack Overflow merupakan situs tanya-jawab populer yang berfokus pada bidang pemrograman. Diskusi yang terjadi pada Stack Overflow adalah diskusi yang sangat aktif dan terpercaya. Dalam [3] disebutkan bahwa lebih dari 90\% pertanyaan yang dilontarkan oleh penanya dijawab tidak lebih dari 12 menit oleh pengguna lainnya. Penanya relatif mendapatkan kepuasan atas jawaban tersebut serta kualitas jawaban yang juga selalu mendapat perhatian dari membernya. Programmer dapat mengakses informasi tersebut melalui kolom pencarian yang tersedia pada situs. Mengingat mesin pencari pada Stack Overflow juga diadopsi dari mesin pencarian teks pada umumnya, maka berbagai penyesuaian pun perlu dilakukan, sehingga hasil pencarian yang diberikan juga belum tentu sesuai dengan kebutuhan pengguna. Hal tersebut umumnya diakibatkan oleh sulitnya merumuskan query yang tepat sebagai masukan sistem pencarian, inkonsistensi penggunaan terminologi, serta berbagai kesulitan lainnya [4]. Oleh karena itu, berbagai penelitian dilakukan untuk menyempurnakan hasil pencarian tersebut.

Penelitian tentang sistem rekomendasi berbasis konteks [5] telah dilakukan. Penelitian tersebut dilatarbelakangi oleh ketidakmampuan mesin pencari dalam memberikan rekomendasi diskusi Stack Overflow yang baik ketika query yang diberikan berupa informasi stack trace. Informasi tersebut biasa muncul ketika terjadi eksepsi saat menjalankan program Java. Informasi tersebut diasumsikan oleh peneliti sebagai konteks permasalahan programmer. Dalam memberikan rekomendasi, sistem akan mengekstrak stack trace yang muncul untuk kemudian dicari strukturnya berdasarkan nama eksepsi, nama method, beserta referensinya. Struktur tersebut akan dijadikan sebagai acuan query yang akan dibangkitkan. Hasilnya, model rekomendasi yang dibangun memiliki performa yang lebih baik dibandingkan dengan model rekomendasi dengan query yang berbasis kata kunci maupun rekomendasi dari mesin pencari pada situs Stack Overflow sendiri. Namun, penelitian ini hanya akan memiliki hasil yang maksimal apabila data diskusi mengandung informasi stack trace pula.

Penelitian lain yang telah dilakukan adalah Seahawk [6]. Seahawk merupakan sistem rekomendasi data diskusi Stack Overflow yang mampu memberikan hasil rekomendasi dengan query yang dibangkitkan secara otomatis berdasarkan kode program yang sedang dibuka pada editor kode Eclipse (IDE). Kode program tersebut diasumsikan sebagai teks bahasa alami sehingga query yang dibangkitkan akan menghasilkan kumpulan kata kunci yang diperoleh dari proses tokenisasi dan beberapa praproses lain terhadap kode program. Pemeringkatan data diskusi dilakukan dengan memanfaatkan Apache Solr dengan model pembobotan TF-IDF. Pengujian dilakukan menggunakan kode program Java yang telah disiapkan sebelumnya. Hasilnya, Seahawk secara umum dapat merekomendasikan diskusi yang berguna bagi programmer. Namun, penelitian ini masih memiliki kekurangan. Hasil rekomendasi menjadi buruk ketika kata kunci bangkitan mengandung unsur singkatan seperti strCmp, usrId, atau lainnya. Padahal, pembentukan term yang baik menjadi kunci sukses perolehan informasi yang tepat dari literatur yang tersimpan [7].

Penelitian lain terkait sistem rekomendasi yaitu penelitian [8] yang menghasilkan JECO (Java Example Code). Penelitian ini mengusulkan sistem rekomendasi kode program pada data diskusi Stack Overflow dengan pemodelan topik LDA (Latent Dirichlet Allocation). Query yang digunakan berupa kata kunci yang dimasukkan secara manual oleh pengguna. Data diskusi dan query kemudian dicari topik beserta proporsinya menggunakan LDA. Berdasarkan topik tersebut, query dan data diskusi dihitung kesamaannya sehingga didapatkan hasil rekomendasi dengan memanfaatkan Cosine similarity. Hasilnya, JECO mampu merekomendasikan kode program Java ke programmer dengan rata-rata precision dan recall masing-masing sebesar $48 \%$ dan $58 \%$. Namun, term singkatan juga tidak diperhatikan pada penelitian ini, baik pada query maupun data diskusi. Hal tersebut tentu akan mempengaruhi recall pada proses rekomendasi. 
Unsur singkatan biasa muncul pada identifier kode program. Seorang programmer terkadang lebih suka menuliskan string dengan str dalam identifier. Sementara programmer lain lebih suka menulis identifier dalam bentuk lengkap dibandingkan dengan bentuk singkatan. Mengatasi hal tersebut, [9] mengembangkan Lingua::IdSplitter. Algoritma tersebut memiliki kemampuan untuk memisah identifier yang umumnya terdiri atas komposisi term serta mengekspansi term singkatan pada identifier menjadi term lengkap, baik yang menggunakan model penulisan all lowercase maupun camel case. Lingua::IdSplitter dikembangkan mengingat identifier merupakan salah satu sumber informasi yang cukup relevan untuk memahami sebuah program. Selain itu, identifier yang lengkap cenderung lebih memudahkan program untuk dipahami [10]. Pemisahan identifier oleh Lingua::IdSplitter dilakukan dalam dua tahap, yakni hard split dan soft split. Hard split dilakukan untuk memisahkan identifier berdasarkan karakter tertentu seperti tanda garis bawah (underscore) atau berdasarkan model penulisan camel case. Sedangkan soft split akan memisah identifier yang tidak terlalu terlihat tanda pemisahnya. Hal ini dilakukan dengan bantuan kamus kata untuk mendapatkan himpunan kandidat katanya. Kandidat kata tersebut selanjutnya akan diperingkat berdasarkan otomata yang dibangun berdasarkan himpunan kandidat kata. Himpunan kata dengan skor tertinggi akan menjadi keluaran Lingua::IdSplitter. Penelitian ini membandingkan algoritma yang diusulkan dengan algoritma-algoritma lain yang sejenis. Hasilnya, algoritma ini mampu menghasilkan term yang telah dipisah dan diekspansi dengan tingkat f-measure sebesar $90 \%$, tidak jauh berbeda dengan hasil algoritma pembanding lainnya.

Penelitian ini mengadopsi Lingua::IdSplitter sebagai algoritma untuk menormalisasi identifier guna meningkatkan performa sistem rekomendasi data diskusi dari Stack Overflow yang pada penelitian-penelitian sebelumnya belum dilakukan. Dengan term yang baik, maka hasil rekomendasi akan menjadi lebih baik pula. Model data yang digunakan adalah model data Bag-ofWords (BOW) yang telah diboboti menggunakan TF-IDF. Model tersebut dipilih mengingat pemodelan topik LDA masih memiliki kekurangan karena tidak adanya proses seleksi atau pemilihan term penting [11] sehingga akan mengakibatkan ketidaksesuaian proporsi topik terhadap dokumen.

\section{TINJAUAN PUSTAKA}

\section{Sistem Rekomendasi}

Sistem rekomendasi merupakan metode yang mampu memberikan rekomendasi dengan memprediksi nilai sebuah item bagi pengguna untuk kemudian mempresentasikan item dengan nilai prediksi tertinggi sebagai hasil rekomendasi. Sistem ini awalnya merupakan sebuah mekanisme information filtering, yakni bertujuan menyaring informasi sebagai akibat membludaknya informasi di internet. Terdapat tiga pendekatan yang bisa digunakan dalam membangun sistem rekomendasi, yaitu rekomendasi berbasis konten, rekomendasi berbasis metode kolaboratif, dan rekomendasi berbasis metode hibrida [12].

Sistem rekomendasi dalam rekayasa perangkat lunak atau sering disebut Recommendation Systems for Software Engineering (RSSE) difungsikan untuk membantu pengembang dalam berbagai aktivitas, mulai dari sugesti informasi, penggunaan ulang kode program, hingga penulisan laporan bug yang efektif [13]. Dengan semakin kompleksnya proses pengembangan perangkat lunak, maka sistem semacam ini sangat dibutuhkan oleh para pengembang, terlebih untuk pengembang dengan tingkat pengalaman yang masih rendah.

\section{Identifier pada Kode Program}

Menurut [14], identifier dalam ranah pemrograman Java adalah rangkaian karakter Java dan digit Java dengan panjang tak hingga. Hal tersebut mengingat identifier umumnya terdiri atas gabungan lebih dari satu kata.Oleh karena itu, programmer sering menggunakan unsur singkatan dalam pembentukannya. Singkatan tersebut biasanya singkatan yang umum digunakan seperti HTML, URL, atau lainnya.

Adapun syarat pembentukan identifier yakni karakter pertama harus berupa karakter Java. Karakter Java sendiri merupakan karakter alfabet (non-simbol), yakni karakter-karakter yang biasa 
digunakan untuk merangkai kata, baik yang terdapat dalam kumpulan karakter latin maupun nonlatin. Sementara itu, digit Java merupakan angka 0-9, baik dalam bentuk karakter latin maupun non-latin. Sebagai tambahan, karakter pada Java didasarkan pada standar pengodean Unicode [14].

Identifier pada Java biasa digunakan untuk menamai elemen-elemen di dalam kode program, seperti class, variabel, atau method [15]. Secara umum, penulisannya mengacu pada konvensi yang dibuat oleh [16], yakni menggunakan aturan camel-case atau underscore seperti pada penulisan variabel myWidth dan MAX_WIDTH. Selain itu, penulisan identifier bersifat case-sensitive, membedakan huruf besar dan kecil, misalnya membedakan antara variabel var2a dan var2A. Namun, dalam penelitian ini, konsep sensitivitas karakter tersebut diabaikan. Langkah tersebut diambil mengingat perbedaan case tidak akan membedakan makna atau konsep identifier.

\section{Praproses pada Sistem Rekomendasi}

Praproses merupakan salah satu hal yang lumrah dilakukan sebelum sebuah data diproses lebih lanjut. Praproses ini digunakan untuk menghapus informasi-informasi yang tidak berguna ataupun menormalisasi data agar data menjadi bersih atau sesuai format serta siap untuk diproses. Mengingat data yang akan dibahas mengandung kode program, maka praproses yang dilakukan salah satunya harus mempertimbangkan pola penulisan kode program [17].

\section{Tokenisasi, Filter Simbol, dan Case Folding}

Jika diberikan kumpulan karakter dan pendefinisian unit dokumen, tokenisasi adalah proses pemotongan kumpulan karakter tersebut menjadi potongan-potongan yang disebut token. Gambar 1 merupakan contoh tokenisasi dengan pemisah berupa karakter spasi (white space). Lebih dari itu, duplikasi token yang telah ditiadakan (token unik) sering disebut sebagai term pada bidang ilmu temu kembali informasi [4]. Mengiringi tokenisasi, penghapusan simbol atau data non-alfabet juga dilakukan. Pada kode program, simbol ini dapat berupa tanda plus $(+)$, minus (-), modulus (\%), atau simbol lain seperti@ (anotasi) [17]. Sebagai tambahan, pengubahan huruf besar ke huruf kecil (case folding) juga biasa dilakukan.

\begin{tabular}{|l|l|l|l|}
\hline 乙 & $\begin{array}{l}\text { even though backquote (') is not a } \\
\text { standard quote character in }\end{array}$ & \begin{tabular}{c}
5 \\
\hdashline
\end{tabular} & $\begin{array}{l}\text { even, though, backquote, is, not, } \\
\text { a, standard, quote, character, in }\end{array}$ \\
\hline
\end{tabular}

Gambar 1. Hasil tokenisasi, filter simbol, dan case-folding pada data teks

\section{Normalisasi dengan Lingua::IdSplitter}

Cara pemisahan identifier pada Lingua::IdSplitter dilakukan melalui dua tahap, yakni hard split dan soft split. Hard split dilakukan untuk memisahkan identifier berdasarkan karakter tertentu seperti tanda garis bawah (underscore) atau berdasarkan aturan penulisan camel case. Sementara itu, soft split akan memisahkan identifier yang tidak terlalu terlihat (tanda) pemisahnya [9]. Ilustrasi proses pemisahan dan ekspansi ini dapat dilihat pada Gambar 2.

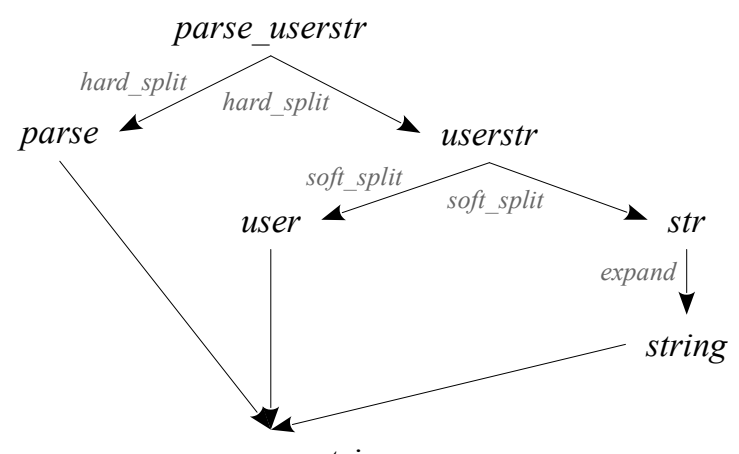

parse, user, string

Gambar 2. Mekanisme pemisahan dan ekspansi identifier [9] 
Soft split dilakukan salah satunya dengan bantuan kamus kata (akronim dan singkatan) untuk mendapatkan himpunan kandidat katanya. Apabila kandidat kata tersebut tidak ditemukan dalam kamus, maka Lingua::IdSplitter akan memotong identifier dengan jumlah karakter tertentu untuk kemudian dicek validitas katanya. Kandidat kata tersebut selanjutnya akan diperingkat berdasarkan otomata yang dibangun berdasarkan himpunan kandidat kata. Himpunan kata dengan skor tertinggi akan menjadi keluaran Lingua::IdSplitter. Ilustrasi hasil penskoran himpunan kandidat kata dapat dilihat pada Tabel 1. Sedangkan otomata yang dibangun dapat dilihat pada Gambar 3.

Tabel 1. Himpunan kandidat hasil split berdasarkan skor tertinggi [9]

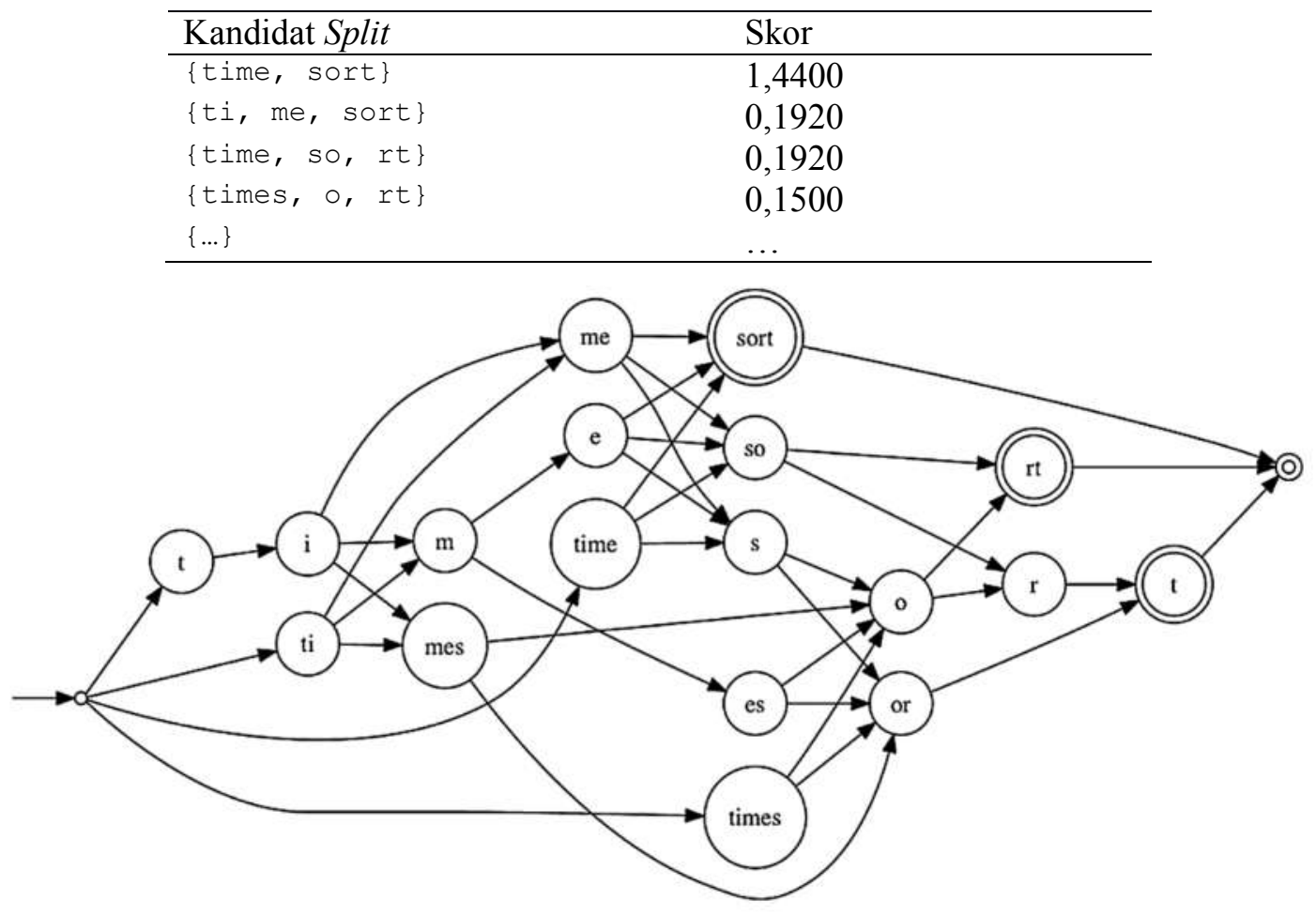

Gambar 3. Otomata untuk identifier timesort [9]

Otomata pada Gambar 3 digunakan untuk menghitung skor kandidat hasil pemisahan. Dengan melihat skor kandidat kata pada Tabel 1, didapatkan bahwa kandidat term time dan sort adalah term yang paling baik untuk menjadi hasil pemisahan atas identifier timesort.

\section{Penghapusan Stop Word}

Penghapusan stop word adalah proses penghapusan term yang tidak memiliki arti, tidak relevan, atau term yang sangat umum. Term yang diperoleh dari tahap tokenisasi dicek dalam suatu stop list, apabila sebuah kata masuk di dalam stop list maka kata tersebut tidak akan diproses lebih lanjut. Stop list tersimpan dalam suatu dokumen yang dimuat saat pemrosesan term. Stop list yang digunakan pada penelitian ini sebanyak 571 kata bahasa Inggris ${ }^{1}$.

\section{Stemming}

Stemming dilakukan atas asumsi bahwa kata-kata yang memiliki akar kata yang sama memiliki makna yang serupa sehingga pengguna tidak keberatan untuk memperoleh dokumendokumen yang di dalamnya mengandung kata-kata dengan akar kata yang sama dengan query yang dimasukkan. Teknik stemming dapat dikategorikan menjadi tiga, berdasarkan aturan bahasa tertentu, berdasarkan kamus, atau berdasarkan teknik kemunculan bersama.

\footnotetext{
${ }^{1}$ Dikompilasi oleh Gerard Salton dan Chris Buckley untuk uji coba sistem SMART IR di Cornell University
} 
Adapun stemmer yang paling umum digunakan terhadap dokumen berbahasa Inggris adalah Porter Stemmer yang berbasis aturan bahasa Inggris [4]. Meski masih memiliki kekurangan, metode stemming ini adalah metode yang cukup ringan dengan hasil yang cenderung lebih baik dibanding metode sejenis lainnya. Berkebalikan dengan hal tersebut, stemming berdasarkan kemunculan bersama akan sangat dipengaruhi oleh koleksi kata yang didapatkan dari dokumen. Oleh karena itu, kata yang tidak pernah muncul pada dokumen tidak akan bisa diperoleh akar katanya [18]. Stemming berdasarkan kamus tidak digunakan mengingat hasil berupa stem sudah mencukupi pada studi kasus yang diambil tanpa mengubah stem ke bentuk lema.

\section{Perekomendasian Berdasarkan Similaritas Data}

Perekomendasian baru bisa dilakukan setelah praproses dilakukan. Dengan masukan berupa daftar term, kemudian term tersebut diboboti dengan metode pembobotan umum TF-IDF. Algoritma ini menggabungkan dua konsep penghitungan bobot, yaitu frekuensi kemunculan term $t$ di dalam dokumen atau biasa disebut $\mathrm{TF}$ (term frequency) dan invers frekuensi dokumen, yaitu frekuensi dokumen yang mengandung term $t$ atau biasa disebut IDF (inverse document frequency). Bobot TF dan IDF kemudian digabungkan dengan cara dikalikan menggunakan persamaan (1) untuk mendapatkan bobot komposit berdasarkan pertimbangan kedua kriteria tersebut [4].

$T F-I D F_{t, d}=T F_{t, d} \times I D F_{t}$

dengan $\mathrm{TF}_{t, d}$ adalah frekuensi kemunculan term $t$ pada dokumen $d$ dan $\operatorname{IDF}_{t}$ adalah invers frekuensi dokumen untuk term $t$ yang dihitung menggunakan persamaan (2):

$I D F_{t}=1+\log \frac{N}{D F_{t}+1}$

dengan $\mathrm{N}$ adalah total dokumen pada koleksi/korpus dan $\mathrm{DF}_{t}$ adalah jumlah dokumen yang mengandung term $t$.

Pembobotan setiap term yang telah dilakukan akan direpresentasikan dalam ruang vektor (vector space model) dalam bentuk matriks term-dokumen sehingga setiap dokumen akan berbentuk sebagai sebuah (fitur) vektor. Vektor-vektor tersebut yang kemudian dihitung kemiripannya dengan pendekatan Cosine similarity. Ilustrasi Cosine similarity dapat dilihat pada Gambar 4.

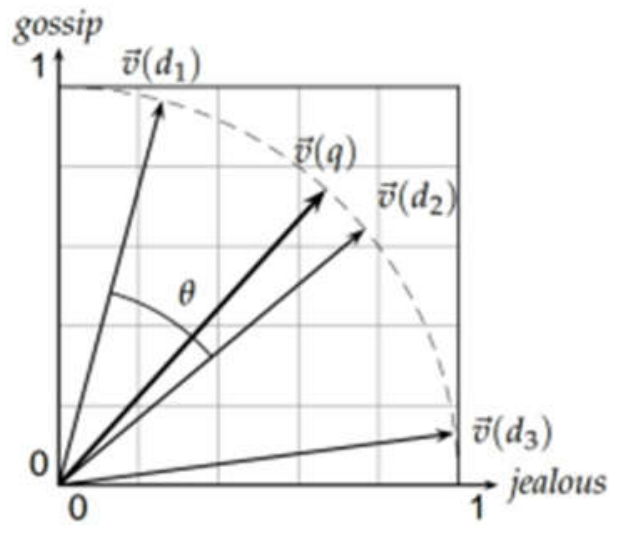

Gambar 4. Penentuan kesamaan dokumen (vektor) berdasarkan sudut yang terbentuk [4]

Melihat Gambar 4, semakin kecil sudut yang terbentuk antara dua vektor, maka semakin mirip kedua dokumen tersebut. Adapun persamaan yang digunakan adalah:

$\operatorname{sim}\left(d_{1}, d_{2}\right)=\frac{\overrightarrow{d_{1}} \cdot \overrightarrow{d_{2}}}{\left|\overrightarrow{d_{1}}\right|\left|\overrightarrow{d_{2}}\right|}$

dengan $d_{1}$ adalah vektor fitur dokumen ke-1 dan $d_{2}$ adalah vektor fitur dokumen ke-2. 


\section{Stack Overflow Sebagai Sumber Data Rekomendasi}

Diskusi pada Stack Overflow umumnya berupa data teks. Sehingga, sangat memungkinkan untuk digunakan dalam membangun sistem rekomendasi yang berbasis teks. Pada Stack Overflow, pengguna umumnya mencantumkan potongan kode program pada pertanyaan ataupun jawaban. Ciri lainnya, pengguna juga terkadang mencantumkan gambar yang mampu mendukung pemahaman terhadap pertanyaan ataupun jawaban pengguna. Selain bertanya dan menjawab, pengguna Stack Overflow diberi fasilitas untuk melakukan vote terhadap pertanyaan maupun jawaban. Pertanyaan yang mendapat banyak vote bisa dikategorikan sebagai pertanyaan yang penting dan merupakan permasalahan yang sering terjadi. Sedangkan jawaban dengan status accepted menandakan jawaban tersebut merupakan jawaban yang sangat bisa dipertimbangkan sebagai solusi yang paling tepat. Vote dirupakan dengan ikon segitiga menghadap ke atas (vote up) dan ke bawah (vote down).

\section{Evaluasi Sistem Rekomendasi}

Karena model sistem rekomendasi yang diteliti adalah rekomendasi berbasis konten, maka sistem dapat dievaluasi dengan menggunakan perhitungan precision dan recall [4] berdasarkan query yang dimasukkan. Precision merupakan rasio jumlah dokumen relevan yang dikembalikan terhadap jumlah seluruh hasil yang dikembalikan. Persamaannya adalah:

Precision $=\frac{\#(\text { dokumen relevan yang dikembalikan })}{\#(\text { dokumen yang dikembalikan })}$

Sedangkan Recall merupakan rasio jumlah dokumen relevan yang dikembalikan terhadap jumlah seluruh dokumen yang relevan. Persamaannya adalah:

Recall $=\frac{\#(\text { dokumen relevan yang dikembalikan })}{\#(\text { dokumen yang relevan })}$

Kedua pengukuran tersebut akan memiliki jangkauan nilai mulai 0 hingga 1 (floating point) atau sering pula dirupakan dalam bentuk persentase dengan jangkauan nilai mulai 0 hingga 100 .

\section{METODE}

Penelitian ini menggunakan kerangka proses sebagaimana yang ditunjukkan pada Gambar 5. Rekomendasi didapatkan dari dua tahap yakni tahap pengindeksan yang hanya dijalankan sebanyak satu kali dan tahap perekomendasian data diskusi. Tahap pengindeksan harus dilakukan terlebih dahulu agar sistem rekomendasi dapat dijalankan.

\section{Data Masukan}

Masukan pada penelitian ini terbagi menjadi dua jenis, yakni masukan untuk tahap pengindeksan dan masukan untuk tahap perekomendasian. Masukan untuk tahap pengindeksan berupa teks diskusi (pertanyaan dan jawaban) yang diambil dari Stack Overflow. Data diambil dengan bantuan Stack Exchange Data Explorer ${ }^{2}$. Data yang diambil adalah data dengan label (tag) Java yang berjumlah 153 data. Data tersebut terdiri atas 34 data tentang topik sorting, 34 data tentang topik database, 32 data tentang topik text file, 34 data tentang topik graphics, dan 19 data tentang topik thread. Spesifikasi data ini adalah spesifikasi data yang digunakan oleh [8].

Adapun masukan untuk tahap perekomendasian merupakan potongan kode program (*.java) yang dimasukkan oleh pengguna. Kode program yang diambil sebanyak 32 buah dan didapatkan secara acak dari GitHub ${ }^{3}$ dengan spesifikasi: 8 program tentang thread synchronization, 8 program tentang accessing MySQL, 8 program tentang bubble sort, serta 8 program tentang draw rectangle.

\footnotetext{
${ }^{2}$ Tools tersedia di: http://data.stackexchange.com/stackoverflow/query/new

${ }^{3}$ Lihat http://github.com
} 


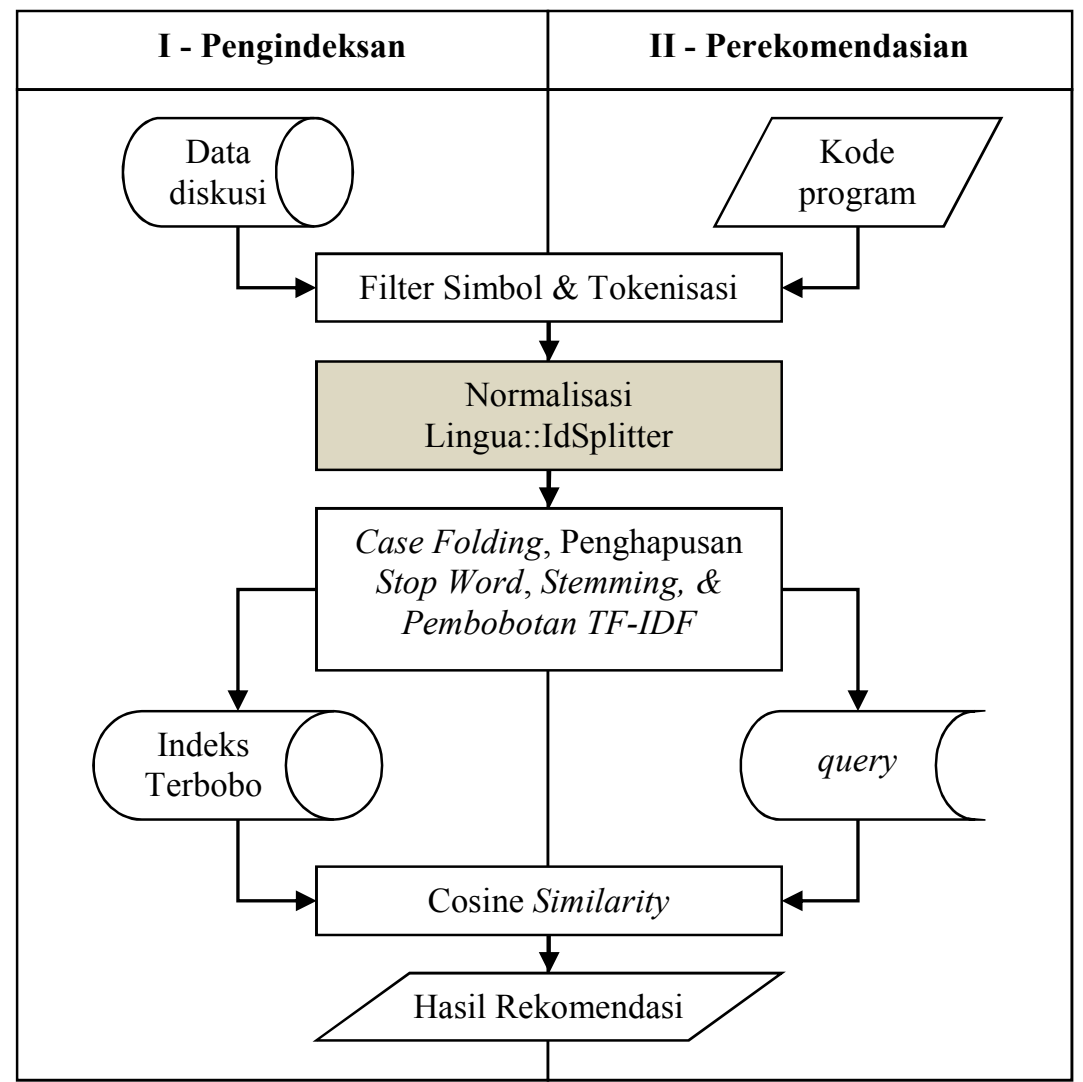

Gambar 5. Desain sistem rekomendasi dengan normalisasi Lingua::IdSplitter

\section{Filter Simbol}

Data masukan yang mengandung simbol non-alfabet seperti titik koma (;), tanda tanya (?), dan lain-lain akan dihapus sehingga yang tersisa hanya karakter alfabet. Sedangkan tanda titik (.) akan diubah menjadi spasi karena tanda titik digunakan oleh Java untuk memisahkan objek atau class dengan membernya. Selain itu, karena data diskusi berupa data HTML, maka tag-tag HTML pada diskusi juga akan dihilangkan. Selain mengandung tag HTML, dokumen web terkadang juga mengandung simbol yang dirupakan dalam bentuk entitas HTML seperti \&lt; yang ketika ditampilkan di peramban web akan muncul sebagai simbol kurang dari $(<)$. Entitas HTML tersebut juga akan dihapus sebelum data diproses lebih lanjut. Gambar yang disertakan pada diskusi juga akan dihapus mengingat tag <img> pada data hanya memuat lokasi gambar saja pada server. Dengan kata lain, dokumen HTML akan diubah bentuknya menjadi teks plain.

\section{Tokenisasi}

Data yang telah difilter kemudian ditokenisasi sehingga akan didapatkan daftar term. Model tokenisasi yang digunakan adalah word token, yakni pemisahan term berdasarkan karakter spasi (white space).

\section{Normalisasi Term dengan Lingua::IdSplitter dan Case Folding}

Term-term hasil tokenisasi akan dinormalisasi dengan Lingua::IdSplitter. Normalisasi ini akan mengubah identifier yang umumnya mengandung gabungan kata serta mengekspansi singkatan menjadi kata lengkap. Term yang memiliki variasi huruf besar dan huruf kecil selanjutnya akan diubah semuanya ke huruf kecil. Hal ini dimaksudkan untuk menyamaratakan semua karakter ke bentuk huruf kecil. Sebagai contoh, identifier BufferedImage akan dinormalisasi menjadi buffered dan image, createText akan dinormalisasi menjadi create dan text, serta fillRect akan dinormalisasi menjadi fill dan rectangle. 
Mengingat Lingua::IdSplitter merupakan modul Perl, maka pada penelitian ini, Lingua::IdSplitter akan difungsikan sebagai program eksternal yang akan dieksekusi pada aplikasi berbasis Java yang dikembangkan dengan bantuan objek Runtime dan Process sehingga pada akhirnya akan dihasilkan $\geq 1$ term setiap normalisasi dijalankan.

\section{Penghapusan Stop Word}

Daftar term yang telah diperoleh selanjutnya difilter kembali untuk menghilangkan termterm yang merupakan term umum (stop word) seperti term the, $a$, or, dan lain-lain sebagaimana yang muncul pada daftar stop list yang digunakan.

\section{Stemming}

Daftar term yang telah difilter dengan stop word selanjutnya akan diubah lagi bentuknya dengan proses stemming untuk mengurangi variasi kata yang memiliki akar kata (stem) yang sama. Sebagai contoh, term following akan berubah menjadi follow, buffered akan menjadi buffer, image akan menjadi imag, graphics akan menjadi graphic, serta rectangle akan menjadi rectangl dengan memanfaatkan Porter Stemmer.

\section{Pembobotan TF-IDF}

Term yang telah didapatkan selanjutnya dihitung frekuensi kemunculannya serta diboboti dengan menggunakan TF-IDF berdasarkan persamaan (1). Dengan demikian, akan didapatkan daftar term unik beserta bobotnya terhadap data diskusi. Hasil pembobotan ini akan menghasilkan fitur vektor untuk tiap-tiap data diskusi.

\section{Cosine Similarity}

Penghitungan Cosine similarity digunakan untuk membandingkan antara query yang dimasukkan dengan data diskusi yang sudah tersedia dalam bentuk indeks terbobot (vektor). Selanjutnya hasil pembandingan akan diperingkat berdasarkan tingkat kemiripannya menggunakan persamaan (3).

\section{Evaluasi Hasil}

Evaluasi pada penelitian ini dilakukan dengan tujuan untuk mengetahui kualitas perbaikan metode rekomendasi yang memanfaatkan proses normalisasi identifier menggunakan Lingua::IdSplitter melalui penghitungan nilai precision dan recall berdasarkan persamaan (4) dan (5). Nilai-nilai tersebut akan dibandingkan dengan nilai precision maupun recall yang dihasilkan oleh sistem rekomendasi yang tidak memanfaatkan proses normalisasi identifier. Mengingat data yang digunakan berasal dari [8], maka hasil penelitian ini juga akan dilihat keselarasannya dengan penelitian tersebut. Selain itu, guna mengetahui kemampuan Lingua::IdSplitter dalam meningkatkan performa rekomendasi, akan digunakan pula data diskusi alternatif sejumlah 80 buah (20 diskusi/topik) dengan identifier singkatan yang muncul pada data dengan proporsi 60:20 (ada singkatan : tidak ada singkatan). Identifier singkatan muncul terutama sebagai identifier-identifier yang merupakan term kunci topik.

Data uji (query) masukan pada sistem ini adalah kode program Java yang berjumlah 32 buah sebagaimana yang telah dipaparkan sebelumnya. Setiap kode program yang dimasukkan, diharapkan mampu menghasilkan rekomendasi diskusi sesuai topik dari kode program. Hasil rekomendasi yang akan dihitung performanya adalah 15 data dengan nilai bobot dokumen tertinggi pertama sebagaimana yang dilakukan oleh [6].

\section{HASIL DAN PEMBAHASAN}

\section{Pengujian dengan Kode Program Terkait Thread Synchronization}

Berdasarkan grafik pada Gambar 6 (a), dapat dilihat bahwa nilai precision untuk data yang dinormalisasi dengan Lingua::IdSplitter memiliki jangkauan antara 0,2 hingga 0,73 dengan median 
0,63 sementara data yang tidak dinormalisasi memiliki jangkauan antara 0,27 hingga 0,73 dengan median 0,67. Sedangkan apabila dilihat dari nilai recall, sebagaimana tampak pada Gambar 6 (b), diketahui bahwa recall yang diperoleh ketika data dinormalisasi yakni antara 0,23 hingga 0,85 dengan median 0,73 sementara data yang tidak dinormalisasi yakni antara 0,31 hingga 0,85 dengan median 0,77. Dengan demikian, dapat disimpulkan bahwa proses normalisasi tidak dapat meningkatkan nilai precision maupun recall untuk query dengan topik thread synchronization.

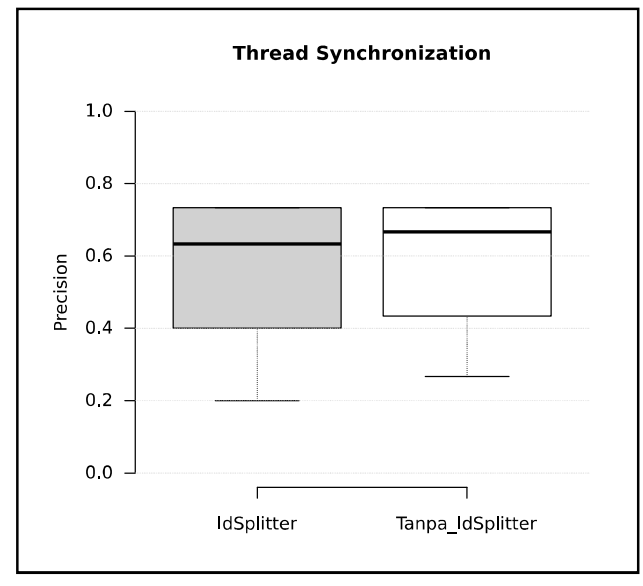

(a) Precision

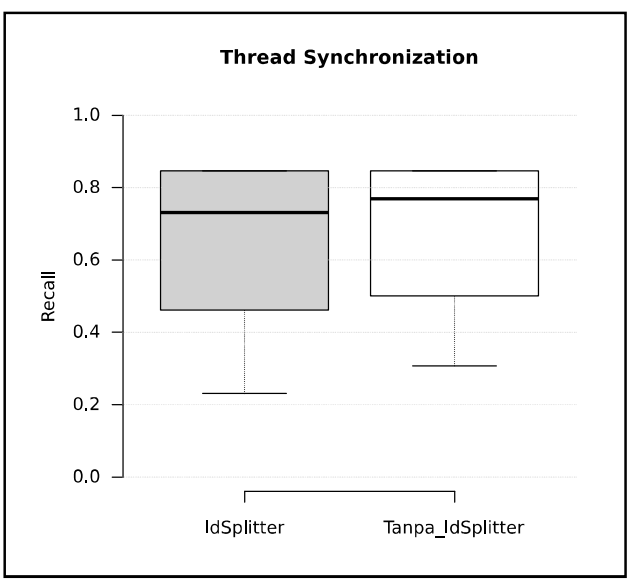

(b) Recall

Gambar 6. Perbandingan performa untuk topik thread synchronization

Hal ini disebabkan oleh tidak ditemukannya identifier synchronize yang disingkat menjadi sync pada data diskusi sebagaimana yang lumrah digunakan oleh programmer dalam menyingkat identifier. Oleh karena itu, normalisasi (ekspansi) term tidak berdampak terhadap kasus query dengan topik thread synchronization ini. Selain itu, sinkronisasi thread juga umum menggunakan konsep exception dengan jenis Interruptedexception. Pemisahan identifier tersebut menjadi Interrupted dan Exception justru menurunkan skor dokumen terkait thread synchronization karena term exception lumrah ditemukan pada topik-topik selainnya.

\section{Pengujian dengan Kode Program Terkait Accessing MySQL}

Berdasarkan grafik pada Gambar 7 (a), dapat dilihat bahwa nilai precision untuk data yang dinormalisasi dengan Lingua::IdSplitter memiliki jangkauan antara 0,27 hingga 0,4 dengan median 0,3 sementara data yang tidak dinormalisasi memiliki jangkauan antara 0,33 hingga 0,4 dengan median 0,37 . Sementara apabila dilihat dari nilai recall, sebagaimana tampak pada Gambar 7 (b), diketahui bahwa recall yang diperoleh ketika data dinormalisasi yakni antara 0,23 hingga 1 dengan median 0,75 sementara data yang tidak dinormalisasi yakni antara 0,83 hingga 1 dengan median 0,92. Dengan demikian, dapat disimpulkan bahwa proses normalisasi juga tidak dapat meningkatkan nilai precision maupun recall untuk query dengan topik accessing MySQL. Hal ini antara lain disebabkan oleh hasil ekspansi identifier jabc menjadi $j$, database, dan c. Perluasan tersebut justru membuat direkomendasikannya data-data diskusi lain yang mengandung term database meski tidak memiliki term $j$ dbc yang menjadi ciri umum bahasan tentang pengaksesan MySQL. Selain itu, pemisahan identifier mysql menjadi my dan sql juga turut menurunkan performa rekomendasi. Pemisahan tersebut justru mengakibatkan hilangnya term penting mysq 1 dalam mewakili data diskusi terkait accessing MySQL.

Normalisasi (pemisahan) dapat memberikan peningkatan hasil rekomendasi untuk query kode program org.embulk. output. MySQLOutputPlugin.java yang berisi tentang kode program untuk melakukan insert ke basis data MySQL secara massal. Tanpa normalisasi, sistem menjadikan identifier seperti batchInsert, mysqlBatchInsert, dan newBatchInsert sebagai term penting query. Secara logika, term-term tersebut memang tepat mewakili query. Namun, hal tersebut tidak didukung oleh sampel data diskusi, tidak ada satupun topik data diskusi yang membahas tentang proses insert secara massal. Jika demikian, setidaknya sistem bisa merekomendasikan data diskusi 
tentang proses insert pada MySQL secara umum. Akan tetapi, kenyataannya tidak. Efek tersebut dapat dilihat pada pencilan nilai precision pada titik 0,13 dan recall pada titik 0,33 untuk proses rekomendasi yang tidak menggunakan normalisasi Lingua::IdSplitter.

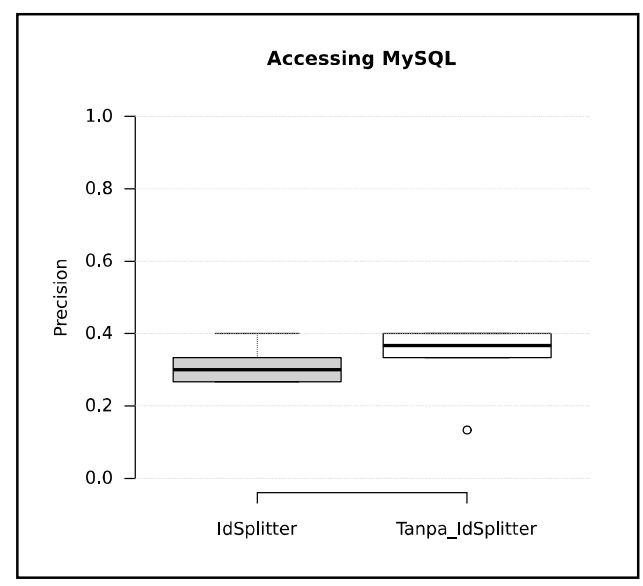

(a) Precision

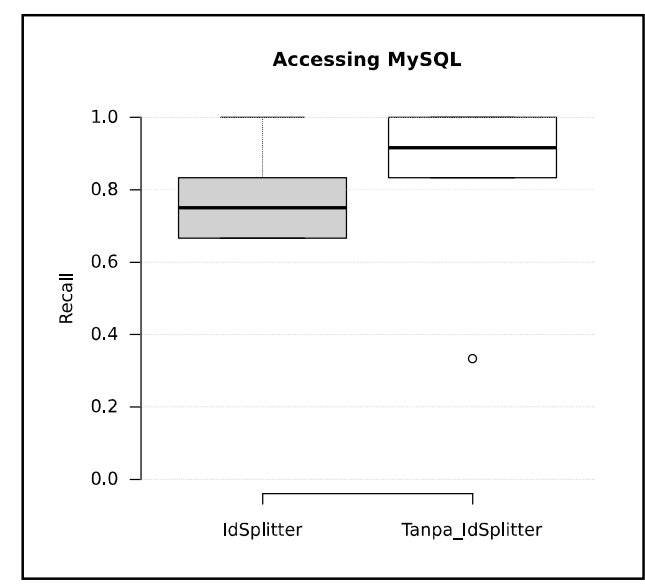

(b) Recall

Gambar 7. Perbandingan performa untuk topik accessing MySQL

\section{Pengujian dengan Kode Program Terkait Bubble Sort}

Grafik pada Gambar 8 (a) menunjukkan bahwa nilai precision untuk data yang dinormalisasi dengan Lingua::IdSplitter memiliki jangkauan antara 0 hingga 0,27 dengan median 0,17 sementara data yang tidak dinormalisasi memiliki jangkauan antara 0,13 hingga 0,27 dengan median 0,2. Sementara apabila dilihat dari nilai recall, sebagaimana tampak pada Gambar 8 (b), diketahui bahwa recall yang diperoleh ketika data dinormalisasi yakni antara 0 hingga 0,8 dengan median 0,5 sementara data yang tidak dinormalisasi yakni antara 0,4 hingga 0,8 dengan median 0,6 . Dapat disimpulkan bahwa proses normalisasi juga tidak dapat meningkatkan nilai precision maupun recall untuk query dengan topik bubble sort. Hal ini antara lain disebabkan oleh hasil pemisahan identifier Bubblesort menjadi bubble dan sort. Pemisahan tersebut justru membuat meningkatnya skor data diskusi tentang sorting yang lain, yang menggunakan metode selain bubble sort. Ekspansi pada topik ini juga tidak terlalu berpengaruh mengingat identifier bubble maupun sort jarang dirupakan dalam bentuk singkat.

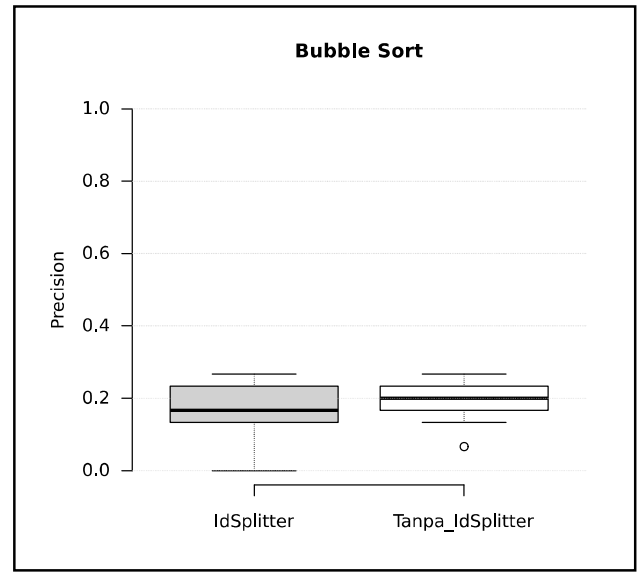

(a) Precision

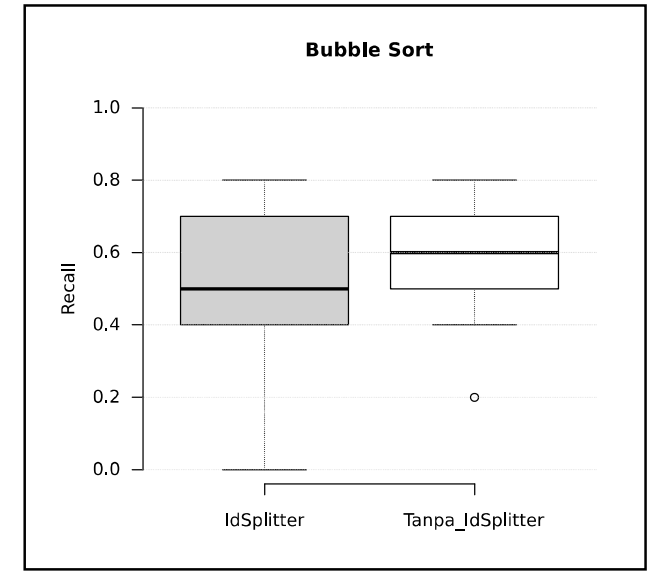

(b) Recall

Gambar 8. Perbandingan performa untuk topik bubble sort 


\section{Pengujian dengan Kode Program Terkait Draw Rectangle}

Berdasarkan grafik pada Gambar 9 (a), dapat dilihat bahwa nilai precision untuk data yang dinormalisasi dengan Lingua::IdSplitter memiliki jangkauan antara 0,2 hingga 0,47 dengan median 0,37 sementara data yang tidak dinormalisasi memiliki jangkauan antara 0,13 hingga 0,47 dengan median 0,3 .

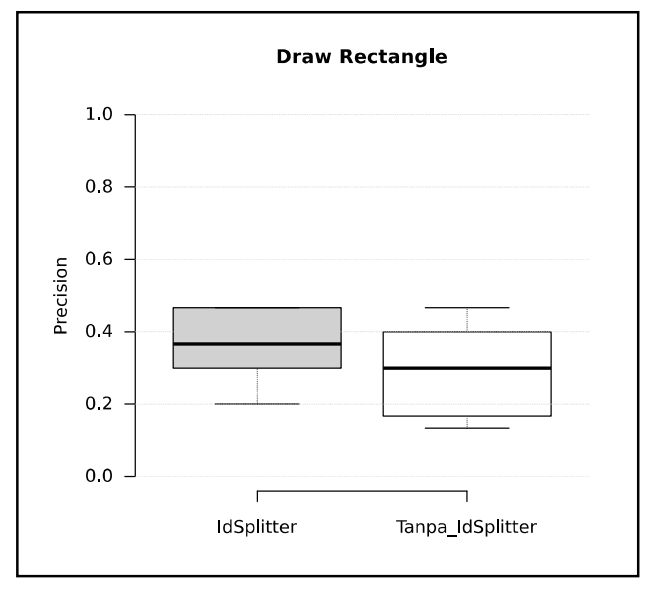

(a) Precision

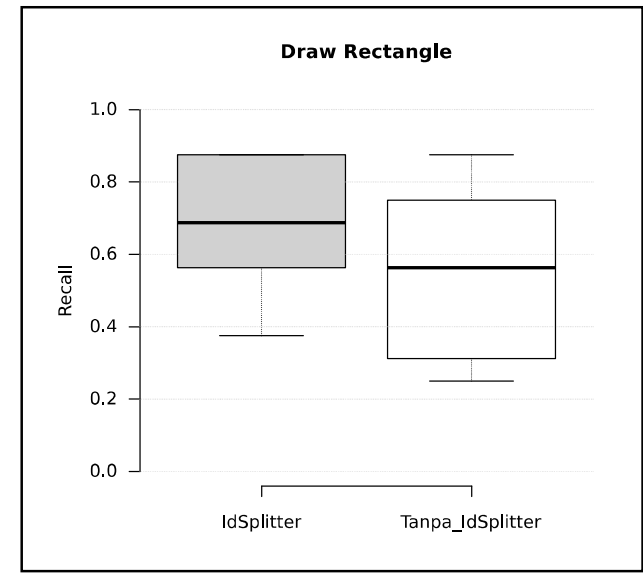

(b) Recall

Gambar 9. Perbandingan performa untuk topik draw rectangle

Sementara apabila dilihat dari nilai recall, sebagaimana tampak pada Gambar 9 (b), diketahui bahwa recall yang diperoleh ketika data dinormalisasi yakni antara 0,38 hingga 0,88 dengan median 0,69 sementara data yang tidak dinormalisasi yakni antara 0,25 hingga 0,88 dengan median 0,56 . Dengan demikian, dapat disimpulkan bahwa proses normalisasi dapat meningkatkan nilai median precision maupun recall masing-masing sebesar 7\% dan $13 \%$ untuk query dengan topik draw rectangle. Hal ini antara lain disebabkan oleh pemisahan identifier DrawFeature menjadi Draw dan Feature, DrawRectangle menjadi Draw dan Rectangle, serta DrawRectangleoptions menjadi Draw, Rectangle, dan options. Identifier dalam bentuk terpisah lebih banyak ditemui pada data diskusi. Oleh karena itu, proses normalisasi menjadi penting. Selain itu, pemisahan dan ekspansi identifier fillRect menjadi fill dan Rectangle serta drawRect menjadi draw dan Rectangle memberikan dampak positif terhadap hasil rekomendasi, mengingat teks diskusi yang ada lebih banyak menggunakan kata lengkap dibandingkan singkatan.

\section{Uji Coba Menggunakan Data Alternatif}

Hasil uji coba menggunakan data alternatif dengan dominasi identifier yang mengandung singkatan dapat dilihat pada Gambar 10. Pengujian ini menghasilkan nilai-nilai precision dan recall yang sama, sehingga representasinya hanya ditampilkan dalam satu grafik saja.

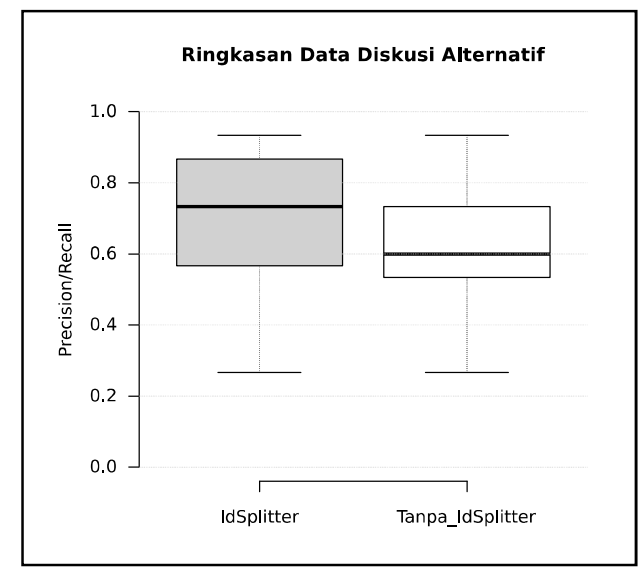

Gambar 10. Ringkasan perbandingan uji coba data alternatif 
Berdasarkan grafik pada Gambar 10, dapat dilihat bahwa nilai precision dan recall baik untuk data yang dinormalisasi dengan Lingua::IdSplitter maupun tidak memiliki jangkauan yang sama antara 0,27 hingga 0,93 . Akan tetapi, nilai median keduanya berbeda. Nilai median untuk data yang dinormalisasi mampu mencapai 0,73 . Sedangkan nilai median untuk data yang tidak dinormalisasi hanya mampu mencapai 0,6 . Dengan demikian, untuk data alternatif ini, proses normalisasi mampu meningkatkan nilai precision dan recall sebesar 13\%.

\section{Ringkasan Hasil Uji Coba}

Berdasarkan hasil pengujian yang telah dijelaskan untuk tiap-tiap topik, diketahui bahwa proses normalisasi dengan Lingua::IdSplitter hanya berpengaruh positif terhadap rekomendasi query dengan topik draw rectangle. Hal ini disebabkan oleh keberadaan identifier rectangle pada data diskusi maupun query, baik berupa singkatan maupun term lengkap. Sedangkan berdasarkan uji coba terhadap data alternatif yang telah dipilih, diketahui bahwa normalisasi identifier menggunakan Lingua::IdSplitter juga berpengaruh positif terhadap hasil rekomendasi dilihat dari nilai median yang dihasilkan. Hal tersebut juga dipengaruhi oleh keberadaan identifier pada data diskusi yang ditulis dalam bentuk singkatan.

Adapun apabila dilihat keselarasannya dengan penelitian [8] yang menggunakan model topik dalam merekomendasikan data diskusi, penggunaan model bobot TF-IDF masih cukup bisa diandalkan dengan melihat nilai median recall umum yang bisa dihasilkan oleh sistem pada data uji yang sama, yakni sebesar 0,67. Namun, perbaikan masih perlu dilakukan mengingat nilai median precision umum yang dihasilkan hanya mampu mencapai 0,33. Hal ini diakibatkan oleh ketidaktepatan pemilihan identifier-identifier yang layak untuk dinormalisasi, baik terkait kasus ketidaktepatan pemisahan komposisi term maupun pengekspansian term penuh dari term singkatan sebagaimana yang telah dijelaskan sebelumnya.

\section{KESIMPULAN}

Berdasarkan hasil penelitian, dapat disimpulkan bahwa:

1. Proses normalisasi identifier menggunakan Lingua::IdSplitter mampu meningkatkan nilai median precision sebesar 7\% dan nilai median recall sebesar 13\% khusus untuk data diskusi dengan topik draw rectangle pada data uji awal.

2. Proses normalisasi identifier juga secara umum mampu meningkatkan nilai median precision maupun recall sebesar $13 \%$ pada data uji alternatif.

\section{UCAPAN TERIMA KASIH}

Penulis ingin mengucapkan terima kasih kepada Kementerian Riset, Teknologi, dan Pendidikan Tinggi RI (sebelumnya: Dikti) atas dukungan finansialnya dalam bentuk Beasiswa Unggulan.

\section{DAFTAR PUSTAKA}

[1] Cegielski, C. G. and Hall, D. J., 2006. What Makes A Good Programmer? Communications of the ACM, 49(10), pp.73-75.

[2] LaToza, T. D., Venolia, G., and DeLine, R., 2006. Maintaining Mental Models: A Study of Developer Work Habits. Proceedings of the 28th international conference on Software engineering, ACM, pp.492-501.

[3] Anderson, A., Huttenlocher, D., Kleinberg, J., and Leskovec, J., 2012. Discovering Value from Community Activity on Focused Question Answering Sites: A Case Study of Stack Overflow. Proceedings of the 18th ACM SIGKDD international conference on Knowledge discovery and data mining, $A C M$, pp.850-858.

[4] Manning, C. D., Raghavan, P., and Schütze, H., 2008. Introduction to Information Retrieval. Cambridge: Cambridge University Press. 
[5] Cordeiro, J., Antunes, B., and Gomes, P., 2012. Context-Based Recommendation to Support Problem Solving in Software Development. Recommendation Systems for Software Engineering (RSSE), 2012 Third International Workshop, IEEE, pp.85-89.

[6] Ponzanelli, L., Bacchelli, A., and Lanza, M., 2013. Leveraging Crowd Knowledge for Software Comprehension and Development. Software Maintenance and Reengineering (CSMR), 2013 17th European Conference, IEEE, pp.57-66.

[7] Krauthammer, M. and Nenadic, G., 2004. Term identification in the biomedical literature. Journal of biomedical informatics, 37(6), pp.512-526.

[8] Arwan, A., Rochimah, S., and Akbar, R. J., 2015. Source Code Retrieval on StackOverflow Using LDA. Information and Communication Technology (ICoICT), 2015 3rd International Conference, IEEE, pp.295-299.

[9] Carvalho, N. R., Almeida, J. J., Henriques, P. R., and Varanda, M. J., 2015. From Source Code Identifiers to Natural Language Terms. Journal of Systems and Software, 100, pp.117128.

[10] Lawrie, D., Morrell, C., Feild, H., and Binkley, D., 2007. Effective identifier names for comprehension and memory. Innovations in Systems and Software Engineering, 3(4), pp.303318.

[11] Hu, D. J., 2009. Latent Dirichlet Allocation for Text, Images, and Music. University of California, San Diego.

[12] Adomavicius, G. and Tuzhilin, A., 2005. Toward the Next Generation of Recommender Systems: A Survey of the State-of-the-Art and Possible Extensions. Knowledge and Data Engineering, IEEE Transaction, 17(6), pp.734-749.

[13] Robillard, M. P., Walker, R. J., and Zimmermann, T., 2010. Recommendation Systems for Software Engineering. Software, IEEE, 27(4), pp.80-86.

[14] Gosling, J., Joy, B., Steele, G., Bracha, G., and Buckley, A., 2015. Chapter 3. Lexical Structure, (online), (https://docs.oracle.com/javase $/ \mathrm{specs} / \mathrm{jls} / \mathrm{se} 8 / \mathrm{html} / \mathrm{jls}-3 . \mathrm{html}$, diakses 20 Juli 2016).

[15] Vohra, D., Baesens, B., Backiel, A. and Vanden Broucke, S., 2015. Beginning Java Programming: The Object-oriented Approach. John Wiley \& Sons.

[16] Sun Microsystems, 1997. Java Code Conventions. Sun Microsystems, Inc.

[17] Mahmoud, A. and Niu, N., 2011. Source Code Indexing for Automated Tracing. Proceedings of the 6th International Workshop on Traceability in Emerging Forms of Software Engineering, $A C M$, pp.3-9.

[18] Jivani, A. G., 2011. A Comparative Study of Stemming Algorithms. Int. J. Comp. Tech. Appl, 2(6), pp.1930-1938. 